\title{
Waktu Tempuh Perjalanan Penduduk Perumahan Puri Yuhana Permai dan Bukit Khatulstiwa
}

\author{
Gideon Irianto Minanga ${ }^{\star 1}$, Rais Rachman ${ }^{\star 2}$, Monika D. M. Palinggi ${ }^{\star 3}$ \\ *1 Mahasiswa Program Studi Teknik Sipil, Universitas Kristen Indonesia Paulus, Makassar, Indonesia \\ gidion@gmail.com \\ *2,3 Dosen Program Studi Teknik Sipil, Universitas Kristen Indonesia Paulus, Makassar, Indonesia \\ rais.rachman@gmail.com dan monika.datu@gmail.com
}

\begin{abstract}
ABSTRAK
Fenomena yang terjadi di Kota Makassar dalam permasalahan waktu tempuh adalah lebih banyak pengguna kendaraan pribdadi dibandingkn dengan pengguna jasa angkutan umum. Pertumbuhan ekonomi di Kota Makassar yang sangat pesat berpengaruh pada daya beli masyarakat dan meningkatkan jumlah kepemilikan kendaraan bermotor. Konsekuensinya perjaanan menjadi lebih Panjang dan waktu tempuh yang dibutuhkan menjadi lebih lama dan lebih Panjang dari penggunaan kendaraan pribadi. Penelitian ini bertujuan untuk mengidentifikasi variabel-variabel bebas yang mempengaruhi waktu tempuh pekerja yang berdomisili di Perumahan Puri Yuhana Permai dan Bukit Khatulisiwa untuk sampai ke tempat kerja, dan memodelkan waktu tempuh berdasarkan variabel bebas yang signifikan terhadap waktu tempuh pekerja tersebutmenggunakan metode regresi linear berganda SPSS 22.0. Hasil Penelitian pada masing-masing perumahan menunjukkan bahwa variabel yang berpengaruh signifikan terhadap waktu tempuh perumahan Puri Yuhana Permai adalah moda (X3) dan adalah jarak tempuh (X4), dan Bukit Khtulisiwa adalah jarak tempuh (X4). Serta diketahui bahwa dominasi urutan waktu tempuh perumahan puri yuhana permai (15-30 Menit) 47,3\%, (30-45 Menit) 32,7\%, (<15 Menit) 10,9\%, (60 Menit) 9,1\%. Sedangkan untuk Perumahan Bukit Khatulistiwa (15-30 Menit) 37,3\%, (30-45 Menit) 28\%, (<15 Menit) 18,7\%, (60 Menit) atau 16\%.
\end{abstract}

Kata Kunci: Jam Keberangkatan pekerja, penduduk, perumahan, waktu tempuh.

\begin{abstract}
The phenomenon that occurs in Makassar City in terms of travel time is that there are more private vehicle users compared to users of public transportation services. The rapid economic growth in Makassar City affects the people's purchasing power and increases the number of motor vehicle ownership. As a consequence, the trips are longer and the travel time needed is longer and longer than using private vehicles. This study aims to identify the independent variables that affect the travel time of workers who live in Puri Yuhana Permai Housing and Khatulisiwa Hill to get to work, and model travel time based on independent variables that are significant to the travel time of these workers using the multiple linear regression method SPSS 22.0. . The results of the research on each housing show that the variables that have a significant effect on the travel time of Puri Yuhana Permai housing are the mode (X3) and the distance traveled (X4), and the Khtulisiwa Hill is the distance traveled (X4). And it is known that the dominance of the travel time sequence of the Yuhana Yuhana housing complex (15-30 minutes) 47.3\%, (30-45 minutes) $32.7 \%,(<15$ minutes) $10.9 \%,(60$ minutes) $9,1 \%$. Meanwhile, for Bukit Khatulistiwa Housing (15-30 minutes) 37.3\%, (30-45 minutes) 28\%, (<15 minutes) $18.7 \%$, (60 minutes) or $16 \%$.
\end{abstract}

Keywords: Time of departure of workers, residents, housing, travel time.

\section{PENDAHULUAN}

Pertumbuhan kepadatan penduduk yang secara langsung berpengaruh pula pada perkembangan ekonomi, social serta politik membuat bertambahnya jumlah pemukiman penduduk di Kota Makassar. Menurut Badan Pusat Statistik, Kota Makassar memliki jumlah penduduk sekitar 1,5 juta jiwa per tahun 2019 dan angka pertumbuhan penduduknya sendiri adalah 1,41 persen tiap tahunnya berdasarkan data dari Dinas Pengendalian Kependudukan dan Keluarga Berencana Kota Makassar [1]. Dengan adanya peningkatan jumlah pemukiman yang signifikan pada Kota Makassar membuat jumlah kendaraan bermotor juga semakin meningkat yang menyebabkan terjadinya kepadatan lalu lintas. 
Berdasarkan data dari SAMSAT kota Makassar angka peningkatan kendaraan bermotor ialah $7 \%$ tiap tahunnya, dimana hal ini tentunya berdampak pada kepadatan arus lalu lintas. Kepadatan arus lalu lintas dapat mengakibatkan terjadinya kemacetan, tundaan waktu perjalanan dan rendahnya tingkat kenyamanan serta terjadinya penurunan pelayanan ruas jalan (kapasitas jalan). Hal ini juga berpengaruh langsung pada durasi atau waktu tempuh perjalanan yang diperlukan untuk mencapai tujuan pengendara. Untuk mempersingkat waktu perjalanan, informasi dari durasi waktu tempuh sangat penting untuk pemilihan rute sehingga waktu yang digunakan dapat lebih efisien [2].

Waktu tempuh merupakan lamanya waktu yang dibutuhkan kendaraan melewati suatu jarak lokasi dengan kecepatan rata - rata tertentu. Besarnya waktu tempuh pada suatu ruas jalan sangat tergantung dari besarnya arus dan kapasitas ruas jalan tersebut [3]. Efisiensi waktu sangat berperan penting menunjang progres kemajuan suatu kota besar seperti Kota Makassar serta meningkatkan pelayanan public yang berperan besar dalam mensejahterakan masyarakat. Hal inilah yang melatar belakangi penulis untuk meneliti dan mengkaji tentang durasi atau waktu tempuh perjalanan tersebut dalam sebuah karya tulis yang berjudul Analisis Waktu Tempuh Perjalanan Penduduk Perumahan Puri Yuhana dan Bukit Khatulistiwa.

Peneliti sebelumnya malakukan studi tentang perjalanan penduduk antara lain, Rachman et.al (2013) melakukan penelitian tentang Model Bangkitan Perjalanan Komuter dari Perumahan Pinggiran Kota di Makassar [4]. Lulu at.al (2019) meneliti tentang Bangkitan Perjalanan Penduduk Di Kecamatan Alak Kota Kupang [5]. Rachman at.al (2013) meneliti tentang Model Bangkitan Perjalanan Komuter Pinggiran Kota Makassar (Studi Kasus Perumahan Tirasa Pratama) [6]. Putra 2013) meneliti tentang Model Bangkitan Pergerakan Penduduk [7]. Rachman R. (2018) melakukan penelitian tentang Karakteristik perjalanan komuter dari wilayah pinggiran Kota Makassar [8].

Selain itu yang malakukan studi tentang waktu perjalanan antara lain, Rachman et.al (2017) melakukan penelitian tentang studi tentang waktu tempuh perjalanan momuter dari wilayah pinggiran Kota Makassar [9]. Rachman et.al (2020) melakukan penelitian tentang waktu tempuh perjalanan penduduk perumahan Dosen UNHAS Kota Makassar [10].

\section{METODE PENELITIAN}

\section{Lokasi Penelitian}

Penelitian ini dilakukan di 2 perumahan yang berbeda yaitu Perumahan Puri Yuhana Permai dan Bukit Khatulistiwa yang terletak di Jalan Perintis Kemerdekaan Km. 13, Daya, Makassar. Dimana kedua perumahan tersebut memiliki posisi yang berhadapan dan dipisahkan oleh Jalan Perintis kemerdekaan.

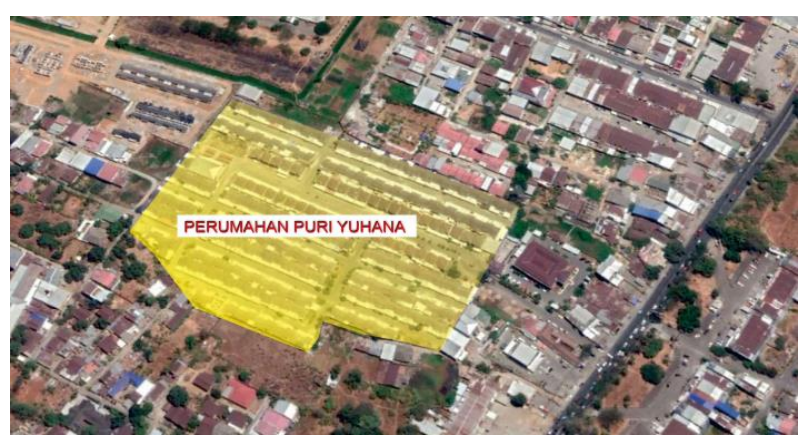

Gambar 1. Perumahan Puri Yuhana

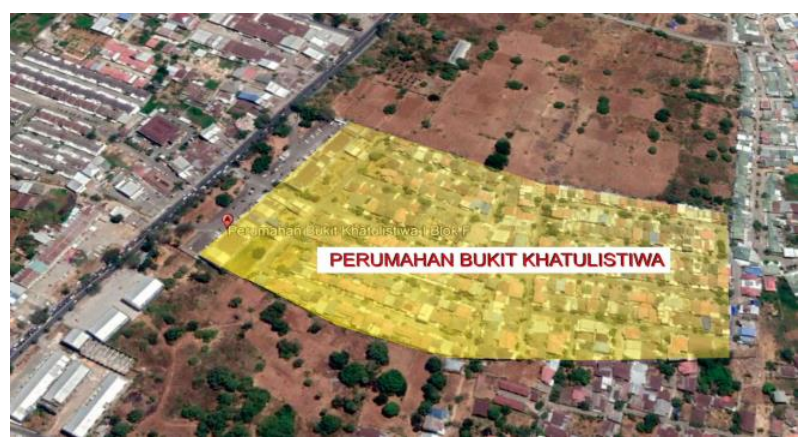

Gambar 2. Perumahan Bukit Khatulistiwa

\section{Metode Pengumpulan Data}

a. Data Primer

Data primer merupakan data karakteristik penduduk yang didapatkan langsung dari hasil pembagian kuesioner atau wawancara serta observasi secara langsung. adapun data primer dalam penelitian ini variabel bebas adalah jenis kelamin, usia, moda, jarak tempuh dan waktu keberangkatan sedangkan variabel tak bebas adalah waktu tempuh yng diperlukan untuk sampai ke kantor.

\section{b. Data Sekunder}

Data Sekunder merupakan data yang tidak diperoleh langsung atau merupakan suatu observasi dan pengumpulan data yang dilakukan oleh pihak lain. Dalam hal ini yang menjadi data sekunder dalam penelitian ini adalah peta lokasi, dan jumlah penduduk.

\section{Metode Pengambilan Sampel}

Pengambilan data jumlah sampel dari populasi Perumahan Puri Yuhana Permai dilakukan secara Proportionate Stratified Random Sampling dengan perhitungan rumus Slovin jumlah sampel yang 
digunakan pada perumahan Puri Yuhana Permai adalah sebanyak 55 sampel. Pengambilan data jumlah sampel dari populasi

Perumahan Bukit Khatulistiwa juga dilakukan secara Proportionate Stratified Random Sampling dengan perhitungan rumus Slovin dan jumlah sampel yang digunakan pada perumahan Puri Yuhana Permai adalah sebanyak 75 sampel.

Dalam penyusunan tugas akhir ini ditetapkan 5 variabel bebas yang diasumsikan dapat menimbulkan serta mempengaruhi waktu tempuh (Y), lima variabel tersebut antara lain: (X1) Jenis Kelamin, (X2) Usia, (X3) Moda yang Digunakan, (X4) Jarak Tempuh (dari rumah ke tempat kerja), (X5) Jam Keberangkatan.

\section{Analisis Data}

Analisis data adalah proses pengolahan data menjadi suatu informasi sehingga mudah dipahami dan dapat memberi sousi pada masalah - masalah yang berkaitan dengan penelitian. Dalam penelitian ini analisis data menggunakan perangkat lunak SPSS (Statistical Package for Social Science). Dalam pengolahan data menggunakan SPSS variabel bebas dan variabel tak bebas diberikan poin atau skor atau bobot nilai yang diberikan untuk masing-masing jawaban dari responden untuk di input ke dalam program SPSS untuk memudahkan peneliti dalam melakukan analisis.

\section{a. Korelasi}

Korelasi merupakan suatu angka yang menunjukkan arah dan kuatnya hubungan antar variable atau lebih. Pada kasus ini variable tersebut dinyatakan dalam positif atau negative, sedangkan kuatnya hubungan dinyatakan dalam besarnya koefisien korelasi. Korelasi adalah hubungan yang saling mempengaruhi satu sama lain (Sutrisno Hadi, 1995). Besar kecilnya korelasi dinyatakan dalam bentuk angka. Keeratan hubungan antara dua variabel dapat diketahui dari korelasinya.

\section{b. Analisis Regresi Linear}

Analisis regresi adalah suatu teknik yang menghasilkan suatu hubungan dalam bentuk numerik untuk melihat bagaimana dua variabel dapat saling terkait. Dalam hal ini variabel bebas adalah jenis kelamin, usia, jenis moda yang digunakan, jarak tempuh ke tempat kerja dan waktu keberangkatan sedangkan untuk variabel terikat adalah lama waktu tempuh untuk sampai ke tempat kerja. Analisis regresi linear berganda dapat digunakan untuk menemukan hubungan antara suatu variabel yang tak bebas dengan dua variabel bebas, maka model persamaan umum regresi linear berganda adalah :

$$
Y=a+b_{1} X_{1}+b X_{2}+\ldots+b_{n} X n
$$

\section{c. Uji Simultan (Uji-F)}

Pengujian ini tak lain bertujuan untuk mengetahui seluruh variabel bebas apakah memiliki pengaruh yang signifikan terhadap variabel terikat. Dalam bahasan statistic ada beberapa macam tingkat signifikansi yaitu $5 \%$ dan $10 \%$. Dari hasil output program SPSS, nilai $F$ dapat dilihat pada tabel ANOVA.

\section{d. Uji Parsial Nilai Rata-Rata (Uji-t)}

Pada analisi uji parsial atau Uji-t dilakukan dengan menggunakan program SPSS versi 17 mengukur dan menguji perbedaan rata-rata dua variable dari dua variabel dari sampel yang berbeda dengan asumsi variansi kedua sampel tersebut tidaklah sama.

\section{ANALISIS DAN PEMBAHASAN}

1. Karakteristik Responden

Karakteristik responden dalam penelitian ini pada masing-masing perumahan berdasarkan pada jumlah sampel dari rumus slovin adalah 55 sampel dari puri yuhana dan 75 sampel dari bukit khatulistiwa yang didapat dari rumah penduduk yang berbeda. Data-data dari karakteristik yang berdasarkan variable dugaan awal dimana sumber informasinya diperoleh dari penyebaran kuesioner yang berisi pertanyaan yang dapat memberikan gambaran karakteristik penduduk di Perumahan Puri Yuhana Permai dan Bukit Khatulistiwa

\section{a. Jenis Kelamin}

Salah satu variabel yang dianggap dapat mempengaruhi waktu tempuh perjalanan penduduk adalah jenis kelamin. Jenis kelamin dianggap dapat mempengaruhi perilaku berkendara seseorang, sehingga mempengaruhi waktu tempuh untuk sampai ke tempat kerja. Adapun persentase jumlah laki-laki dan perempuan pada kedua perumahan dapat dilihat pada table 1

Tabel 1. Persentase Jenis kelamin penduduk

\begin{tabular}{ccc}
\hline Jenis Kelamin & $\begin{array}{c}\text { Perumahan Puri } \\
\text { Yuhana }\end{array}$ & $\begin{array}{c}\text { Perumhanan Bukit } \\
\text { Khatulistiwa }\end{array}$ \\
\hline Laki-laki & 58,2 & 53,3 \\
Perempuan & 41,8 & 46,7 \\
\hline
\end{tabular}

Dari tabel 1, persentase jenis kelamin penduduk pada perumahan puri yuhana, jenis kelamin laki-laki adalah $58,2 \%$ serta jenis kelamin perempuan berjumlah $41,8 \%$. Karakteristik jenis kelamin pada perumahan Bukit Khatulistiwa Jumlah jenis kelamin laki-laki $53,3 \%$ serta jenis perempuan berjumlah $46,7 \%$. 


\section{b. Usia}

Sama dengan jenis kelamin, usia seseorang juga dianggap dapat mempengaruhi perilaku dalam berkendara sehingga dapat mempengaruhi waktu tempuh perjalanan kedua perumahan tersebut. Hasil analisis usia ke dua perumahan dapat dilihat pada tabel 2 .

Tabel 2. Persentase usia penduduk

\begin{tabular}{ccc}
\hline Usia (tahun) & $\begin{array}{c}\text { Perumahan Puri } \\
\text { Yuhana }\end{array}$ & $\begin{array}{c}\text { Perumhanan Bukit } \\
\text { Khatulistiwa }\end{array}$ \\
\hline $10-19$ & 10,90 & 16,00 \\
$20-29$ & 21,80 & 25,30 \\
$30-39$ & 30,90 & 40,00 \\
$40-50$ & 36,40 & 18,70 \\
\hline
\end{tabular}

dari tabel 2 persentase jumlah penduduk pada perumahan Puri Yuhana dimana usia 10-19 tahun sebanyak 10,9\%, usia 20-29 tahun berjumlah $21,8 \%$, usia $30-39$ tahun berjumlah $30,9 \%$, dan usia 40-50 tahun berjumlah 36,4\%. Persentase usia penduduk Perumahan Bukit Khatulistiwa usia 10-19 tahun berjumlah $16,0 \%$, usia $20-29$ tahun $25,3 \%$, usia 30-39 tahun 40\%, dan usia 40-50 tahun berjumlah $18,7 \%$.

\section{c. Moda yang Digunakan}

Variabel pemilihan moda yang menjadi sarana transportasi oleh responden untuk berangkat ke tempat kerja tentunya memliki pengaruh pada waktu tempuh perjalan. Karakteristik pemilihan moda untuk kedua perumahan seperti pada tabel 3.

Tabel 3. Moda perjalanan Penduduk

\begin{tabular}{ccc}
\hline Jenis Moda & $\begin{array}{c}\text { Perumahan Puri } \\
\text { Yuhana Permai }\end{array}$ & $\begin{array}{c}\text { Perumhanan Bukit } \\
\text { Khatulistiwa }\end{array}$ \\
\hline Mibil Pribadi & 60,00 & 49,30 \\
Motor & 32,70 & 40,00 \\
Angkutan umum & 7,30 & 10,70 \\
\hline
\end{tabular}

Persentase jumlah penduduk yang menggunakan moda transportasi sepeda motor adalah $32,7 \%$, yang menggunakan moda transportasi mobil pribadi adalah $60 \%$ dan yang menggunakan moda transportasi angkutan umum adalah 7,3\%.

Persentase responden yang menggunakan moda transportasi sepeda motor 49,3 yang menggunakan moda transportasi mobil pribadi $40 \%$ dan reponden yang menggunakan moda transportasi angkutan umum adalah $10,7 \%$.

\section{d. Jarak Tempuh}

Jarak dari rumah ke kantor tentunya memiliki pengaruh pada waktu tempuh perjalanan, semakin jauh jarak maka semakin lama juga waktu yang diperlukan untuk sampai ke kantor. Karakteristi jarak tempuh kedua perumahan dapat dilihat pada tabel 4.

Tabel 4. Jarak tempuh penduduk

\begin{tabular}{ccc}
\hline $\begin{array}{c}\text { Jarak Tempuh } \\
(\mathrm{km})\end{array}$ & $\begin{array}{c}\text { Perumahan Puri } \\
\text { Yuhana Permai }\end{array}$ & $\begin{array}{c}\text { Perumhanan Bukit } \\
\text { Khatulistiwa }\end{array}$ \\
\hline $1-2$ & 18,20 & 20,00 \\
$2-5$ & 43,60 & 41,30 \\
$>5 \mathrm{~km}$ & 38,20 & 38,70 \\
\hline
\end{tabular}

Karakteristik jarak tempuh pada tabel 4 menunjukkan jarak tempuh ke tempat kerja sejauh 1-2 $\mathrm{km}$ adalah sebanyak $50,9 \%$, jarak tempuh ke tempat kerja sejauh 2-5 km adalah sebanyak $32,7 \%$, jarak tempuh ke tempat kerja sejauh lebih 5 $\mathrm{km}$ adalah sebanyak $38,2 \%$.

Dari tabel 4, persentase penduduk yang menempuh jarak sejauh $1-2 \mathrm{~km}$ adalah sebanyak $20 \%$, jarak tempuh ke tempat kerja sejauh 2-5 km adalah sebanyak $41,3 \%$, responden dengan jarak tempuh ke tempat kerja sejauh $5 \mathrm{~km}$ adalah sebanyak $38,7 \%$.

\section{e. Waktu Berangkat ke Tempat Kerja}

Waktu keberangkatan sangat berpengaruh pada waktu tempuh karena kemacetan yang biasanya terjadi pada jam tertentu bisa sangat mempengaruhi lama waktu tempuh. Waktu keberangkatan dari kedua perumahan dapat dilihat pada tabel 5 .

Tabel 5. Waktu keberangkatan penduduk

\begin{tabular}{ccc}
\hline $\begin{array}{c}\text { Waktu } \\
\text { keberangkatan }\end{array}$ & $\begin{array}{c}\text { Perumahan Puri } \\
\text { Yuhana Permai }\end{array}$ & $\begin{array}{c}\text { Perumhanan Bukit } \\
\text { Khatulistiwa }\end{array}$ \\
\hline 06:00 - 07:00 & 54,50 & 60,00 \\
07:00 - 08:00 & 30,90 & 21,30 \\
08:00 - 09:00 & 14,60 & 18,70 \\
\hline
\end{tabular}

Tabel 5 menunjukkan persentase penduduk yang berangkat dari perumahan Puri Yuhana Permai pada jam $06.00-07.00$ adalah sebanyak $54,5 \%$, yang berangkat pada pukul 07:00 - 08:00 sebanyak $30,9 \%$, sedangkan yang berangkat pada pukul 08:00 - 09:00 adalah sebanyak 8 orang $(14,5 \%)$.

Waktu keberangkatan dari perumahan Bukit Khatulistiwa seperti pada tabel 5 yang berangkat pada pukul 06:00 - 07:00 sebanyak 60\%, yang berangkat pada pukul 07:00 - 08:00 sebanyak $21,3 \%$ dan yang berangkat pada pukul 08:00 09:00 sebanyak $18,7 \%$.

\section{f. Waktu tempuh}

Waktu tempuh perjalanan penduduk untuk kedua permahan dapat dilihat pada tabel 6 . 
Tabel 6. Waktu tempuh penduduk

\begin{tabular}{ccc}
\hline $\begin{array}{c}\text { Waktu tempuh } \\
\text { (mnt) }\end{array}$ & $\begin{array}{c}\text { Perumahan Puri } \\
\text { Yuhana Permai }\end{array}$ & $\begin{array}{c}\text { Perumhanan Bukit } \\
\text { Khatulistiwa }\end{array}$ \\
\hline$<15$ & 10,90 & 18,70 \\
$15-30$ & 47,30 & 37,30 \\
$30-45$ & 32,70 & 28,00 \\
$>45$ & 9,10 & 16,00 \\
\hline
\end{tabular}

Dari tabel 6, waktu tempuh penduduk pada perumahan Puri Yuhana Permai $<15$ menit adalah sebanyak $10,9 \%$, untuk waktu tempuh antara 15-30 menit adalah sebanyak $47,3 \%$, waktu tempuh antara 30-45 menit adalah sebanyak $32,7 \%$ dan untuk waktu tempuh lebih besar 45 menit sebanyak $9,1 \%$.

Dari tabel 6, waktu tempuh penduduk pada perumahan Bukit Khatulistiwa dibawah $<15$ menit adalah sebanyak $18,7 \%$, untuk waktu tempuh antara $15-30$ menit sebanyak $37,3 \%$, untuk waktu tempuh antara 30-45 menit sebanyak $28 \%$ sedangkan waktu tempuh lebih besar 45 menit atau lebih adalah sebanyak 12 orang (16\%).

\section{Analisis Korelasi}

Analisis korelasi merupakan studi pembahasan tentang hubungan antara variabel yang dinyatakan dengan koefisien korelasi. . Pada kasus ini variable tersebut dinyatakan dalam positif atau negative, sedangkan kuatnya hubungan dinyatakan dalam besarnya koefisien korelasi.

a. Korelasi Product Momen

Tabel 7. Tabel Korelasi Perumahan Puri Yuhana Permai

\begin{tabular}{|c|c|c|c|c|c|c|c|}
\hline & & $\begin{array}{c}\text { Jenis } \\
\text { Kelamin }\end{array}$ & Usia & Moda & Jarak & $\begin{array}{c}\text { Waktu } \\
\text { Keberangka } \\
\tan \\
\end{array}$ & $\begin{array}{l}\text { Waktu } \\
\text { Tempuh }\end{array}$ \\
\hline Jenis & Pearson Correlation & 1 & -012 & -.110 & .020 & $.344^{\circ}$ & -101 \\
\hline \multirow[t]{2}{*}{ Kelamin } & Sig. (2-tailed) & & .931 & .425 & .883 & .010 & .461 \\
\hline & $\mathrm{N}$ & 55 & 55 & 55 & 55 & 55 & 55 \\
\hline \multirow[t]{3}{*}{ Usia } & Pearson Correlation & .012 & 1 & $.291^{\circ}$ & .195 & .213 & .172 \\
\hline & Sig. (2-tailed) & .931 & & .031 & .154 & .118 & .210 \\
\hline & $\mathrm{N}$ & 55 & 55 & 55 & 55 & 55 & 55 \\
\hline \multirow[t]{3}{*}{ Moda } & Pearson Correlation &. .110 & $.291^{\circ}$ & 1 & .072 & .254 & $.383^{*}$ \\
\hline & Sig. (2-tailed) & .425 & .031 & & .601 & .061 & .004 \\
\hline & $\mathrm{N}$ & 55 & 55 & 55 & 55 & 55 & 55 \\
\hline \multirow[t]{3}{*}{ Jarak } & Pearson Correlation & .020 & .195 & .072 & 1 & $-366^{\prime \prime}$ & $.741^{*}$ \\
\hline & Sig. (2-tailed) & .883 & .154 & .601 & & .006 & .000 \\
\hline & $\mathrm{N}$ & 55 & 55 & 55 & 55 & 55 & 55 \\
\hline Waktu & Pearson Correlation & $.344^{\circ}$ & -.213 & .254 & $-.366^{\prime \prime}$ & 1 & .037 \\
\hline Keberangk & Sig. (2-tailed) & .010 & .118 & .061 & .006 & & .786 \\
\hline atan & $\mathrm{N}$ & 55 & 55 & 55 & 55 & 55 & 55 \\
\hline Waktu & Pearson Correlation & -.101 & .172 & $.383^{*}$ & $.741^{*}$ & -.037 & 1 \\
\hline \multirow[t]{2}{*}{ Tempuh } & Sig. (2-tailed) & .461 & .210 & .004 & .000 & .786 & \\
\hline & $\mathrm{N}$ & 55 & 55 & 55 & 55 & 55 & 55 \\
\hline
\end{tabular}

Tabel 8. Korelasi Perumahan Bukit Khatulistiwa

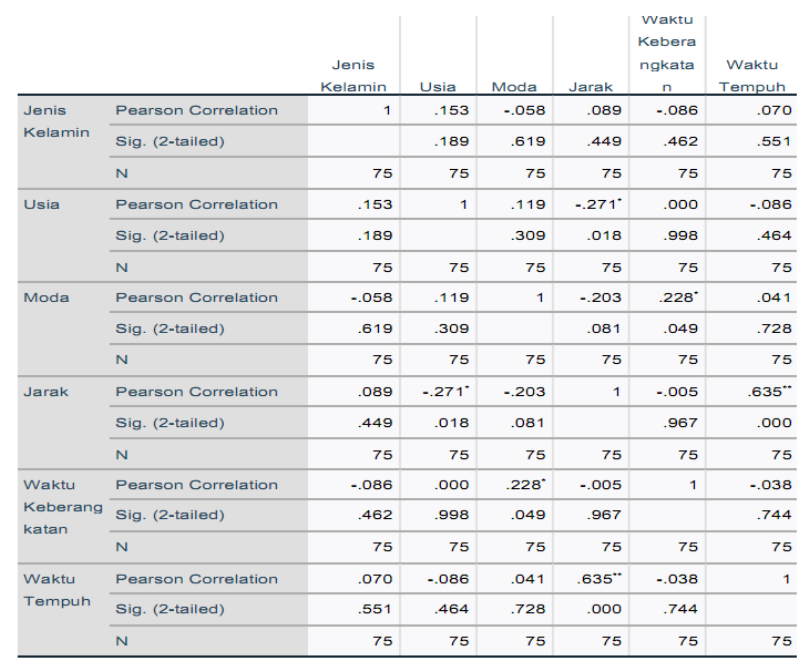

b. Korelasi Ganda Untuk Perumahan Puri Yuhana Permai

Tabel 8. Model Summary Perumahan Puri Yuhana

\begin{tabular}{|c|c|c|c|c|}
\hline \multicolumn{5}{|c|}{ Model Summary } \\
\hline Model & $R$ & R Square & $\begin{array}{c}\text { Adjusted R } \\
\text { Square }\end{array}$ & Std. Error of the Estimate \\
\hline 1 & $.840^{\mathrm{a}}$ & .706 & .676 & .459 \\
\hline
\end{tabular}

Berdasarkan tabel 8 Model Summary untuk perumahan puri yuhana permai, diketahui nilai korelasi $R$ sebesar 0,840 dan berdasarkan Tabel 1 . Pedoman untuk Memberikan Interpretasi Terhadap Koefisien Korelasi, maka dapat diketahui bahwa variabel tak bebas dan variabel bebas memiliki hubungan yang sangat kuat. Untuk koefisien determinasi $\mathrm{R}^{2}$ berdasarkan tabel Summary Model diperoleh nilai sebesar 0,706 atau $70 \%$. Hal ini menunjukkan bahwa 5 variabel bebas $(X)$ yang digunakan dalam penelitian ini berpengaruh sebesar $70 \%$ terhadap variabel tak bebas (Y), Sedangkan sisanya $30 \%$ dipengaruhi oleh variabel atau faktor lain diluar penelitian ini.

c. Korelasi Ganda Untuk Perumahan Bukit Khatulistiwa

Tabel 9. Model Summary Perumahan Bukit Khatulistiwa

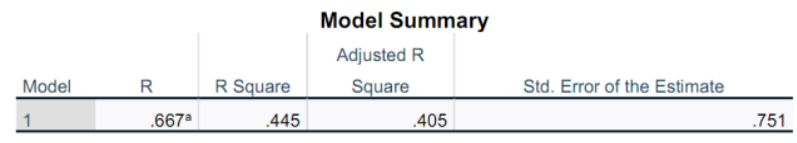

Berdasarkan tabel 4 Model Summary untuk data korelasi perumahan bukit khatulistiwa diketahui nilai korelasi $R$ sebesar 0,667 dan berdasarkan Tabel 1. Pedoman untuk Memberikan Interpretasi Terhadap Koefisien Korelasi, maka dapat diketahui bahwa variabel terikats dan variabel bebas memiliki hubungan yang kuat. Untuk koefisien determinasi 
$\mathrm{R}^{2}$ berdasarkan tabel Summary Model diperoleh nilai sebesar 0,445 atau $44,5 \%$. Hal ini menunjukkan bahwa 5 variabel bebas $(X)$ yang digunakan dalam penelitian ini berpengaruh sebesar $44,5 \%$ terhadap variabel tak bebas $(Y)$, Sedangkan sisanya $56,5 \%$ dipengaruhi oleh variabel atau faktor lain diluar penelitian ini.

\section{Analisis Regresi Linear}

a. Analisis Regresi Linear Berganda Perumahan Puri Yuhana Permai

Tabel 10. Koefisien Regresi Puri Yuhana Permai

\begin{tabular}{|c|c|c|c|c|c|c|}
\hline \multicolumn{7}{|c|}{ Coefficients $^{a}$} \\
\hline \multirow[b]{2}{*}{ Mode } & & \multicolumn{2}{|c|}{$\begin{array}{l}\text { Unstandardized } \\
\text { Coefficients }\end{array}$} & \multirow{2}{*}{$\begin{array}{c}\text { Standardized } \\
\text { Coefficients } \\
\text { Beta } \\
\end{array}$} & \multirow[t]{2}{*}{$t$} & \multirow[t]{2}{*}{ Sig. } \\
\hline & & $\mathrm{B}$ & $\begin{array}{l}\text { Std. } \\
\text { Error }\end{array}$ & & & \\
\hline \multirow[t]{6}{*}{1} & (Constant) & .703 & .470 & & 1.494 & .142 \\
\hline & Jenis Kelamin & .026 & .135 & -.016 & .189 & .851 \\
\hline & Usia & .126 & .066 & .159 & 1.900 & .063 \\
\hline & Moda & .416 & .108 & .327 & 3.852 & .000 \\
\hline & Jarak & .834 & .096 & .754 & 8.719 & .000 \\
\hline & Waktu Keberangkatan & .202 & .103 & .184 & 1.966 & .055 \\
\hline
\end{tabular}

a. Dependent Variable: Waktu Tempuh

Pada perumahan puri yuhana permai dari tabel di atas dapat diketahui bahwa variabel X1,X2 dan X4 yaitu jenis kelamin, usia dan waktu keberangkatan tidak signifikan terhadap variabel dependent karena nilai dari kedua variabel tersebut memliki nilai > 0,05 . Maka variabel variable tersebut dikeluarkan dari perhitungan analisis regresi linear berganda dan kemudian variable yang memiliki nilai signifikansi $<0,05$ di analisis kembali sebagai berikut:

Tabel 11. Korelasi Perumahan Puri Yuhana variable yang baru

\begin{tabular}{|c|c|c|c|c|}
\hline \multicolumn{5}{|c|}{ Correlations } \\
\hline & & Moda & Jarak & Waktu Tempuh \\
\hline \multirow[t]{3}{*}{ Moda } & Pearson Correlation & 1 & .072 & $.383^{* \prime}$ \\
\hline & Sig. (2-tailed) & & .601 & .004 \\
\hline & $\mathrm{N}$ & 55 & 55 & 55 \\
\hline \multirow[t]{3}{*}{ Jarak } & Pearson Correlation & .072 & 1 & $.741^{*}$ \\
\hline & Sig. (2-tailed) & .601 & & .000 \\
\hline & $\mathrm{N}$ & 55 & 55 & 55 \\
\hline Waktu & Pearson Correlation & $.383^{*}$ & $.741^{*}$ & 1 \\
\hline \multirow[t]{2}{*}{ Tempuh } & Sig. (2-tailed) & .004 & .000 & \\
\hline & $\mathrm{N}$ & 55 & 55 & 55 \\
\hline
\end{tabular}

Tabel 12. Model Summary Perumahan Puri Yuhana variable yang baru

\begin{tabular}{|c|c|c|c|c|}
\hline \multicolumn{5}{|c|}{ Model Summary } \\
\hline Model & $\mathrm{R}$ & $R$ Square & Adjusted R Square & $\begin{array}{c}\text { Std. Error of the } \\
\text { Estimate }\end{array}$ \\
\hline & $.812^{\mathrm{a}}$ & .65 & .646 & .480 \\
\hline
\end{tabular}

a. Predictors: (Constant), Jarak, Moda
Tabel 12. Koefisien Regresi Perumahan Puri Yuhana yang baru

\begin{tabular}{|c|c|c|c|c|c|c|}
\hline \multicolumn{7}{|c|}{ Coefficients $^{\mathrm{a}}$} \\
\hline & & \multicolumn{2}{|c|}{$\begin{array}{l}\text { Unstandardized } \\
\text { Coefficients }\end{array}$} & \multirow{2}{*}{$\begin{array}{c}\text { Standardized } \\
\text { Coefficients } \\
\text { Beta }\end{array}$} & \multirow[t]{2}{*}{$\mathrm{t}$} & \multirow[t]{2}{*}{ Sig. } \\
\hline \multicolumn{2}{|l|}{ Model } & $\mathrm{B}$ & Std. Error & & & \\
\hline \multirow[t]{3}{*}{1} & (Constant) & .033 & .249 & & .133 & .895 \\
\hline & Moda & .423 & .103 & .332 & 4.086 & .000 \\
\hline & Jarak & .793 & .090 & .717 & 8.834 & .000 \\
\hline
\end{tabular}

a. Dependent Variable: Waktu Tempuh

Nilai Konstanta sebesar 0,33 ini berarti jika moda yang digunakan, Jarak tempuh, dan jam keberangkatan dengan kondisi yang tetap pada saat survei maka lama waktu tempuh bertambah menjadi 0,33.

Nilai koefisien moda yang digunakan untuk variabel $X_{3}$ adalah 0,423 . Hal ini berarti bahwa setiap kenaikan moda yang digunakan datu satuan variabel maka lama waktu tempuh akan naik sebesar 0,423.

Nilai koefisien jarak yang ditempuh yang digunakan untuk variabel $\mathrm{X}_{4}$ adalah 0,793. Hal ini berarti bahwa setiap kenaikan moda yang digunakan datu satuan variabel maka lama waktu tempuh akan naik sebesar 0,793.

b. Analisis Regresi Linear Berganda Bukit Khatulistiwa

Tabel 13. Koefisien Regresi Bukit Khatulistiwa

\begin{tabular}{|c|c|c|c|c|c|c|}
\hline \multicolumn{7}{|c|}{ Coefficients $^{a}$} \\
\hline \multirow{2}{*}{\multicolumn{2}{|c|}{ Model }} & \multicolumn{2}{|c|}{$\begin{array}{l}\text { Unstandardized } \\
\text { Coefficients }\end{array}$} & \multirow{2}{*}{$\begin{array}{l}\text { Standardized } \\
\text { Coefficients } \\
\text { Beta }\end{array}$} & \multirow[t]{2}{*}{$\mathrm{t}$} & \multirow[t]{2}{*}{ Sig. } \\
\hline & & $\mathrm{B}$ & Std. Error & & & \\
\hline \multirow[t]{6}{*}{1} & (Constant) & .064 & .537 & & .119 & .905 \\
\hline & Jenis Kelamin & .001 & .178 & .000 & .005 & .996 \\
\hline & Usia & .080 & .095 & .080 & .840 & .404 \\
\hline & Moda & .274 & .136 & .190 & 2.013 & .048 \\
\hline & Jarak & .905 & .124 & .695 & 7.268 & .000 \\
\hline & $\begin{array}{l}\text { Waktu } \\
\text { Keberangkatan }\end{array}$ & .097 & .114 & .078 & .847 & .400 \\
\hline
\end{tabular}

a. Dependent Variable: Waktu Tempuh

Pada perumahan bukit khatulistiwa dari tabel di atas dapat diketahui bahwa variabel $X_{1}, X_{2}, X_{3}$, dan $X_{5}$ yaitu jenis kelamin, usia, moda dan waktu keberangkatan tidak signifikan terhadap variabel dependent waktu tempuh karena nilai dari keempat variabel tersebut memliki nilai $>0,05$. Maka variabel variable tersebut dikeluarkan dari perhitungan analisis regresi linear berganda dan kemudian variable yang memiliki nilai signifikansi $>0,05$ di analisis kembali. Sebagai berikut: 
Tabel 14. Tabel korelasi bukit khatulistiwa variable yang baru

\begin{tabular}{|c|c|c|c|}
\hline \multicolumn{4}{|c|}{ Correlations } \\
\hline & & Jarak & Waktu Tempuh \\
\hline \multirow[t]{3}{*}{ Jarak } & Pearson Correlation & 1 & $.635^{\prime \prime}$ \\
\hline & Sig. (2-tailed) & & .000 \\
\hline & $\mathrm{N}$ & 75 & 75 \\
\hline \multirow[t]{3}{*}{ Waktu Tempuh } & Pearson Correlation & $.635^{\prime \prime}$ & 1 \\
\hline & Sig. (2-tailed) & .000 & \\
\hline & $\mathrm{N}$ & 75 & 75 \\
\hline
\end{tabular}

Tabel 15: Tabel model summary bukit khatulistiwa variable yang baru

\begin{tabular}{|c|c|c|c|c|}
\hline \multirow[b]{2}{*}{ Model } & \multicolumn{3}{|c|}{ Model Summary } & \multirow[b]{2}{*}{$\begin{array}{c}\text { Std. Error of the } \\
\text { Estimate }\end{array}$} \\
\hline & $\mathrm{R}$ & R Square & $\begin{array}{l}\text { Adjusted R } \\
\text { Square }\end{array}$ & \\
\hline 1 & $.635^{\mathrm{a}}$ & .403 & .3 & .75 \\
\hline
\end{tabular}

a. Predictors: (Constant), Jarak

Tabel 6. Tabel Koefisien Regresi bukit khatulistiwa variable yang baru

\begin{tabular}{|c|c|c|c|c|c|c|}
\hline \multirow[b]{3}{*}{ Model } & \multicolumn{6}{|c|}{ Coefficients $^{a}$} \\
\hline & & \multicolumn{2}{|c|}{$\begin{array}{l}\text { Unstandardized } \\
\text { Coefficients }\end{array}$} & \multirow{2}{*}{$\begin{array}{c}\text { Standardized } \\
\text { Coefficients } \\
\text { Beta } \\
\end{array}$} & \multirow{2}{*}{$t$} & \multirow{2}{*}{ Sig. } \\
\hline & & B & Std. Error & & & \\
\hline \multirow[t]{2}{*}{1} & (Constant) & .606 & .272 & & 2.227 & .029 \\
\hline & Jarak & .827 & .118 & .635 & 7.019 & .000 \\
\hline
\end{tabular}

a. Dependent Variable: Waktu Tempuh

Dari persamaan di atas maka dapat diinterpretasikan sebagai berikut:

Nilai Konstanta sebesar 0,606 ini berarti jika moda yang digunakan, Jarak tempuh, dan jam keberangkatan dengan kondisi yang tetap pada saat survei maka lama waktu tempuh bertambah menjadi 0,606.

Nilai koefisien jarak yang ditempuh yang digunakan untuk variabel $\mathrm{X}_{4}$ adalah 0,827. Hal ini berarti bahwa setiap kenaikan moda yang digunakan datu satuan variabel maka lama waktu tempuh akan naik sebesar 0,827

4. Pengujian Hipotesis

a. Pengujian Secara Simultan (F-test) Perumahan Puri Yuhana Permai

Tabel 17. ANOVA Perumahan Puri Yuhana Permai

\begin{tabular}{|c|c|c|c|c|c|c|}
\hline \multicolumn{7}{|c|}{ ANOVA $^{a}$} \\
\hline Model & & $\begin{array}{l}\text { Sum of } \\
\text { Squares }\end{array}$ & $\mathrm{df}$ & $\begin{array}{l}\text { Mean } \\
\text { Square }\end{array}$ & $\mathrm{F}$ & Sig. \\
\hline \multirow[t]{3}{*}{1} & Regression & 23.194 & 2 & 11.597 & 50.231 & $.000^{\circ}$ \\
\hline & Residual & 12.006 & 52 & .231 & & \\
\hline & Total & 35.200 & 54 & & & \\
\hline
\end{tabular}

a. Dependent Variable: Waktu Tempuh

b. Predictors: (Constant), Jarak, Moda

Menentukan Tingkat Signifikansi Tingkat signifikasni yang digunakan adalah $10 \%$ atau 0,1
Menghitung uji F

Berdasarkan hasil dari tabel ANOVA, maka diperoleh nilai $F_{\text {hitung sebesar 50,231 Sedangkan }}$ berdasarkan lampiran 1, Tabel titik presentasi distribusi $F$ untuk $\alpha=10 \%$, diperoleh $F_{\text {tabel }}$ sebesar 1,96 .

Kriteria Keputusan :

- $\mathrm{HO}$ : $\mathrm{F}_{\text {hitung }}=\mathrm{F}_{\text {tabel }}$ (Koefisien regresi variabel bebas tidak signifikan terhadap tak bebas).

- H1: $F_{\text {hitung }}>\mathrm{F}_{\text {tabel }}$ (Koefisien regresi variabel bebas signifikan terhadap tak bebas).

Keputusan Uji

Karena nilai $F_{\text {hitung }}>F_{\text {tabel }}$ maka keputusannya adalah menolak $\mathrm{H}_{0}$ dan menerima $\mathrm{H}_{1}$.

b. Penguujian Secara Simultan (F-test) Perumahan khatulistiwa

Tabel 18. ANOVA perumahan bukit khatulistiwa

\begin{tabular}{|c|c|c|c|c|c|c|}
\hline \multicolumn{7}{|c|}{ ANOVA $^{a}$} \\
\hline \multicolumn{2}{|c|}{ Model } & \multirow{2}{*}{$\begin{array}{r}\text { Sum of Squares } \\
28.283\end{array}$} & \multirow{2}{*}{$\frac{\mathrm{df}}{1}$} & \multirow{2}{*}{$\begin{array}{l}\begin{array}{l}\text { Mean } \\
\text { Square }\end{array} \\
28.283\end{array}$} & \multirow{2}{*}{$\frac{F}{49.272}$} & \multirow{2}{*}{$\frac{\text { Sig. }}{.000^{\circ}}$} \\
\hline 1 & Regression & & & & & \\
\hline & Residual & 41.903 & 73 & .574 & & \\
\hline & Total & 70.187 & 74 & & & \\
\hline
\end{tabular}

a. Dependent Variable: Waktu Tempuh

b. Predictors: (Constant), Jarak

Menentukan Tingkat Signifikansi Tingkat signifikasni yang digunakan adalah $10 \%$ atau 0,1

Menghitung uji F

Berdasarkan hasil dari tabel ANOVA, maka diperoleh nilai $F_{\text {hitung sebesar 6,112 Sedangkan }}$ berdasarkan lampiran 1, Tabel titik presentasi distribusi $\mathrm{F}$ untuk $\alpha=10 \%$, diperoleh $\mathrm{F}_{\text {tabel }}$ sebesar 1,93. 3 .

Kriteria Keputusan

- $\mathrm{H} 0$ : $\mathrm{F}_{\text {hitung }}=\mathrm{F}_{\text {tabel }}$ (Koefisien regresi variabel bebas tidak signifikan terhadap tak bebas).

- $\mathrm{H} 1$ : $\mathrm{F}_{\text {hitung }}>\mathrm{F}_{\text {tabel }}$ (Koefisien regresi variabel bebas signifikan terhadap tak bebas).

Keputusan Uji

- Karena nilai $F_{\text {hitung }}>F_{\text {tabel }}$ maka keputusan adalah menolak $\mathrm{HO}$ dan menerima $\mathrm{H} 1$.

c. Pengujian Secara Parsial (t-test) Perumahan Puri Yuhana Permai

Menentukan tingkat signifikansi 
Tingkat signifikansi $(\alpha)$ yang digunakan adalah $10 \%$ atau 0,1

\section{Menghiting Uji t}

Berdasarkan tabel 28 Hasil koefisien antara variabel pada kolom $t$ hitung, untuk moda yang digunakan (X3) sebesar 4,086 dan jarak tempuh (X4) sebesar 8,384. Sedangkan berdasarkan Lampiran tabel titik presentase distribusi t, nilai ttabel adalah sebesar 1,67655.

\section{Kriteria Pengambilan Keputusan}

- HO: $t$ hitung = $t$ tabel (Koefisien regresi variabel bebas tidak signifikan terhadap tak bebas).

- $\mathrm{H} 1$ : $\mathrm{t}$ hitung $\neq \mathrm{t}$ tabel (Koefisien regresi variabel bebas signifikan terhadap tak bebas).

Keputusan Uji

Karena nilai $\mathrm{t}$ hitung $\neq \mathrm{t}$ tabel Ftabel maka keputusannya adalah menolak $\mathrm{HO}$ dan menerima $\mathrm{H} 1$.

\section{d. Pengujian Secara Parsial (t-test) Perumahan Bukit Khatulistiwa}

\section{Menentukan tingkat signifikansi}

Tingkat signifikansi $(\alpha)$ yang digunakan adalah $10 \%$ atau 0,12 )

\section{Menghiting Uji t}

Berdasarkan tabel 26 Hasil koefisien antara variabel pada kolom t hitung, jarak tempuh (X4) sebesar 7,019. Sedangkan berdasarkan Lampiran tabel titik presentase distribusi t, nilai ttabel adalah sebesar 1,99495.

\section{Kriteria Pengambilan Keputusan}

- HO: $t$ hitung = $t$ tabel (Koefisien regresi variabel bebas tidak signifikan terhadap tak bebas).

- $\mathrm{H} 1$ : $\mathrm{t}$ hitung $\neq \mathrm{t}$ tabel (Koefisien regresi variabel bebas signifikan terhadap tak bebas). 4) Keputusan $U \mathrm{Ji} \quad$ Karena nilai $\mathrm{t}$ hitung $\neq \mathrm{t}$ tabel Ftabel maka keputusannya adalah menolak $\mathrm{H} 0$ dan menerima $\mathrm{H} 1$.

\section{Pembahasan}

Dari hasil pengambilan dan pengolahan data didapatkan dominasi waktu tempuh Perumahan Puri Yuhana Permai waktu tempuh antara 15-30 menit sebanyak $47,3 \%$. Waktu tempuh antara 30 45 menit sebanyak 32,7\%. Dibawah 15 menit sebanyak $10,9 \%$, untuk, untuk waktu tempuh diatas 60 menit atau lebih sebanyak 9,1\%. Sedangkan untuk Perumahan Bukit Khatulistiwa duraasi waktu yang paling dominan adalah waktu tempuh antara $15-30$ menit yaitu sebanyak $37,3 \%$ kemudian waktu tempuh antara 30-45 menit adalah $28 \%$ untuk waktu tempuh dibawah 15 menit adalah $18,7 \%$, dan waktu tempuh lebih dari 60 menit adalah $16 \%$.

Adapun variabel yang berpengaruh signifikan terhadap waktu tempuh perumahan Puri Yuhana Permai adalah moda (X3) dan adalah jarak tempuh (X4), dan Bukit Khtulisiwa adalah jarak tempuh (X4). Berikut ini merupakan hasil persamaan yang didapatkan dari penelitian ini: Persamaan Regresi Perumahan Puri Yuhana:

$$
Y=0,033+0,423 X 3+0,793 X 4
$$

Berikut ini merupakan hasil persamaan yang didapatkan dari penelitian ini: Persamaan Regresi Perumahan Puri Yuhana:

$$
Y=0,606+0,827 X 3
$$

\section{KESIMPULAN}

1. Variabel-variabel yang mempengaruhi waktu tempuh perjalanan penduduk Perumahan Puri Yuhana Permai adalah moda atau jenis kendaraan dan jarak tempuh ke tempat kerja. Sedangkan pada perumahan Bukit Khatulistiwa variable yang mempengaruhi hanya jarak tempuh.

2. Berdasarkan pada model waktu tempuh yang didapatkan dari hasil pengolahan data maka dapat disimpulkan bahwa untuk perumahan puri yuhana permai waktu tempuh untuk sampai ke tempat kerja adalah kurang lebih setengah jam dimana hal tersebut dipengaruhi oleh pemilihan moda dimana moda yang paling dominan adalah mobil pribadi dan dipengaruhi pula oleh jarak dimana jarak yang paling dominan adalah I dua sampai lima kilometer. Sedangkan pada perumahan bukit khatulistiwa waktu tempuh yang paling dominan adalah setengah jam dimana hal tersebut hanya dipengaruhi oleh jarak dimana jarak yang paling dominan adalah dua sampai lima kilometer.

\section{DAFTAR PUSTAKA}

[1] Badan Pusat Statistik Kota makassar, 2019, Kota Makassar Dalam Angka 2019. Kota Makassar: BPS Kota Makassar.

[2] J. Khisty C. dan B. K. Lall, 2005, Dasar - Dasar Rekayasa Transportasi, 3 ed., vol. 1. Jakarta: Erlangga.

[3] E. K. Morlok, 1991, Pengantar Teknik dan Perencanaan Transportasi. Jakarta: Erlangga.

[4] R. Rachman, H. Parung, S. Sutomo Tri, dan N. Ali, 2013, "Model Bangkitan Perjalanan Komuter dari Perumahan Pinggiran Kota di 
Makassar," J. Rekayasa Transp., vol. 2, no. 1, Art. no. 1 .

[5] M. R. Lulu, R. Kaho, J. H. Frans, dan E. E. Hangge, 2019, "Bangkitan Perjalanan Penduduk Di Kecamatan Alak Kota Kupang," J. Tek. Sipil, vol. VIII, no. 2, hlm. $193-204$.

[6] R. Rachman, H. Parung, S. Sutomo Tri, dan N. Ali, 2013,"Model Bangkitan Perjalanan Komuter Pinggiran Kota Makassar (Studi Kasus Perumahan Tirasa Pratama)," dalam Prosiding Konfrensi Nasional Pascasarjana Teknik Sipil (KNPTS), hlm. 301-307.

[7] Adris. A. Putra, 2013, "Model Bangkitan Pergerakan Penduduk," TEKNO SIPIL, vol. 11, no. 58, hlm. 19-26.
[8] R. Rachman, 2018, "Study of Commuter Travel Characteristics of Makassar Suburban," Int. J. Innov. Res. Sci. Eng. Technol., vol. 7, no. 2, Art. no. 2, doi: 10.15680/IJIRSET.2018. 0702092.

[9] R. Rachman, H. Parung, S. Trisutomo, dan N. Ali, 2017, "Study On The Travel Behavior Of Worker Living In The Makassar Suburban," J. Civ. Eng. Technol. IAEME Publ., vol. 8, no. 6, Art. no. 6.

[10] R. Rachman, R. Mangontan, dan A. Toding, 2020, "An analysis of the travel time in the Unhas lecturer housing of Makassar city," dalam ICCEE 2019, Bali, Indonesia,vol. 419, doi: 10.1088/1755-1315/419/1/012087. 